\title{
Being a Good Teacher of Black Students? White Teachers and Unintentional Racism
}

\author{
NORA E. HYLAND \\ Rutgers, The State University of New Jersey \\ New Brunswick, New Jersey, USA
}

\begin{abstract}
This ethnographic study describes the roles adopted by four White teachers in the United States during and after they participated in a seminar on teaching antiracism with colleagues at the Woodson Elementary School, the only African American neighborhood school in a small Midwestern city. Each of these teachers self-identified as a good teacher and identified a central metaphor by which she understood her role as a teacher of Black students. By examining the roles and related practices of these teachers, I highlight the disconnect between what researchers have identified as good practices for teaching students of color and how these teachers understand themselves as good teachers. I describe how the roles that each of these four teachers adopted relate to the perpetuation of Whiteness and how such a relation is embedded in their everyday teaching practices and might function to sustain racist practice and ideology in the schooling of students of color. Findings suggest that the ways that these teachers understood their roles as teachers of Black students are intimately linked to how closely their practice represented what is known as culturally relevant pedagogy.
\end{abstract}

Currently, schools in the United States are staffed by primarily White teachers, although the number of students of color from historically marginalized racial groups is growing dramatically (Villegas \& Lucas, 2002). At the same time, Black and Latino students lag significantly behind their White peers in terms of standardized test scores and high school graduation rates (Villegas \& Lucas). It would be unfair to assert that teachers are fully responsible for such racial inequality in education or that they are solely responsible for correcting it. However, we do know that teachers participate in the reproduction of racial inequality and that teachers can mitigate or exacerbate the racist effects of schooling for their students of color depending on their pedagogical orientation. As such, there have been myriad calls for effective teachers of students of color, and there has been

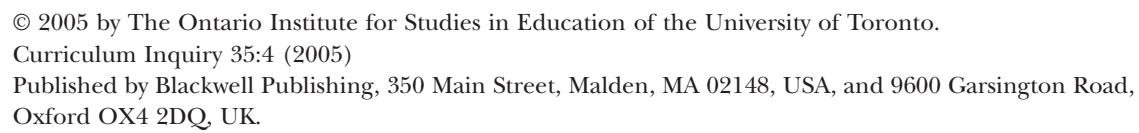


increasing scholarship as to what an effective teacher of students of color is. Most of this work comes from researchers who define themselves as multicultural teacher educators or critical multicultural researchers. These researchers have identified a set of characteristics commonly referred to as culturally relevant, politically relevant, or culturally responsive teaching (Beauboeuf-Lafontant, 1999; Gay, 2000; Ladson-Billings, 1994; Villegas \& Lucas). Within this scholarship, the numbers of teachers identified as culturally relevant are quite few. There are also some self-reports among White teachers who self-identify as successful teachers of their students of color (Landsman, 2001; Michie, 1999; Paley, 2000). These accounts detail the ways that these teachers have been able to examine their own Whiteness and teach in ways that counter White racism.

The research in this field generally points to the idea that successful teachers of students of color identify the public school system as racist and see themselves as part of a larger political struggle for racial justice (Beauboeuf-Lafontant, 1999; Foster, 1997; Ladson-Billings, 1994). A shared history, culture, racial identification, or experience has often soldered these connections between teachers and historically marginalized communities. Moreover, culturally or politically relevant teachers see their connection to the community as integral to their identities as teachers.

The roles and practices adopted by teachers identified as culturally relevant are not determined by the teacher's race, but these teachers do actively identify and resist racism in schools. Given the descriptions of culturally relevant teachers and the rarity of this type of practice, I am led to question how the vast majority of White teachers who teach in schools that serve primarily students of color see their roles as teachers. If they see themselves as successful, how do they define that success? How do they understand what they are doing as White teachers of students of color?

In my ethnographic research of a school staff examining race and racism, I found that most teachers, regardless of race, would describe themselves as good and effective teachers for their predominantly workingclass African American students (Hyland, 2000). In the following pages, I describe the ways that four White teachers from my research at Carter G. Woodson Elementary School ${ }^{1}$ described the primary factor that made each of them effective teachers of their African American students. By doing so, I raise some critical questions about how race and racism operated in the ways that these teachers saw themselves as teachers. By exploring the central metaphors they used to describe their roles as successful White teachers of Black students, I explore how these well-intentioned teachers may unwittingly perpetuate a racist status quo. I also question how critical multicultural teacher educators may more effectively communicate their findings with real teachers in schools primarily serving students of color. 


\section{WHITENESS AND RACISM}

Before telling the stories of these four teachers, it is important to understand how I define and understand Whiteness and racism. I understand race as a historically and socially assigned category. That is, one's race is not biologically determined; rather, it is socially constructed as a result of history, politics, and economics. Historical research has suggested that race has been constructed as a way of categorizing people so that those in power could maintain their positions by minimizing the threat of a unified rebellion (Roediger, 1990, 1994; Zinn, [1980] 1995). The construction of racial categories has played a fundamental role in history, and Whiteness developed in relationship to particular political and economic forces as a way to create an in-group. The construction of an in-group, or dominant group, necessitates the construction of one or more subordinate out-groups, which have been configured in different ways throughout history but have always included people of African descent (Allen, 1994; Ignatiev, 1995; Roediger, 1990, 1994).

Therefore, Whiteness is intimately linked to the subordination and oppression of people of color. "The White race consists of those who partake of the privileges of the White skin in this society. Its most wretched members share a status higher, in certain respects, than those of the most exalted persons excluded from it" (Ignatiev, 1995, p. 1).

In order to discuss how racism operates in our schools and is sustained by well-meaning teachers, we must first understand racism. Feagin and Vera (1995) defined White racism as the "socially organized set of attitudes, ideas, and practices that deny African Americans and other people of color the dignity, opportunities, freedoms, and rewards that this nation offers White Americans" (p. 7). Therefore, White racism refers to something more powerful than individual acts of bigotry, although such acts are related to racism in significant ways. Racism, in the United States, is a system-supported by discourse, ideology, the legal system, and everyday practice-that perpetuates White dominance. White European culture has been assumed, by way of historical and institutional assertions of power, as the superior culture in terms of values, religions, art, languages, and perspectives. At the same time, the cultural features of African Americans, Asian Americans, Native Americans, and Latinas and Latinos have been derogated. Because Whites and their cultural norms dominate the major U.S. institutions, Whites are privileged, and members of other races are disadvantaged. Therefore, racism is essentially about power. One groupin this case, Whites-creates hegemonic ideological and discursive norms that position them as superior to another group-in this case, people of color. Racism relies on institutional power and the mask of normalcy to subordinate people of color.

Analyzing Whiteness is inseparable from a critique of racism because racism is built upon the preservation of Whiteness. Whiteness is made out 
of materials that include socioeconomic status, cultural practices, peer group acceptance, and parental teaching, all of which lead to community participation in ideological constructions that support the "myth of racial neutrality" (Frankenberg, 1997, p. 28). At certain times and locations, people of color are afforded certain benefits of Whiteness, but these benefits are constantly challenged by dominant ideological constructions of race (Twine, 1997). Therefore, White racism is not a problem for people simply because they are White, but because they were raised within a system and context that normalizes racial grouping and has educated them to a worldview that assumes that Whiteness is superior. "Institutionalized racism and the socially constructed category of race has shaped White people's consciousness just as surely as they have shaped people of color, but in a manner that has been largely undefined and unrecognized by Whites, who, as members if the dominant group, often take their Whiteness and the societal racial arrangement for granted" (Kailin, 2002, pp. 18-19).

Few teachers would continue to act in ways that they believed would endanger the educational opportunities of their students. However, sometimes racism is inserted into schools simply by doing what is normal in those schools that primarily serve students of color, or even doing what is seemingly wonderful for students. How teachers identify themselves as teachers can function to sustain or disrupt the institutional and societal racism that lives in the practices of U.S. schools. Through this research, I will describe the ways that four teachers understand their roles as teachers of Black students and how these roles may subtly and sometimes obviously—but surely unwittingly—serve the purposes of Whiteness and White racism.

\section{THE CONTEXT}

This study is part of a 3-year critical ethnographic research project with the staff at the Carter G. Woodson Elementary School as they worked to understand their teaching in terms of race and racism. I gained access to the Carter G. Woodson Elementary School through a university-based interdisciplinary group of action researchers seeking to build bridges between one school and its surrounding community, which is predominantly working class and African American. Before describing my data sources and analysis, it is important to get a sense of the school and community context at the time of this research to fully understand how the community and school operated within a system of White racism.

\section{The Contextual Influence}

The ways that these four teachers shaped their roles as teachers in relationship to Whiteness represents the unique ways that personal history, 
political choice, sense of agency, and pedagogical context interact within individuals. The district presented an "official story" about race that frames how race was supposed to be understood in the community.

Corbel is a midsized Midwestern U.S. city with a population of approximately 68,000. The city houses a large state university. Most of the Black families live on the north side of town, and most of the White families live on the south side of town. Corbel is economically segregated along racial lines as well; the wealthy families, who are predominantly White, live in the southwest section of Corbel. The poor families, who are mostly African American, live in the northeast section of Corbel. Because of these segregated housing patterns, the racial integration of its 11 elementary schools has been achieved by forced bussing of African American students. Like most school districts in our nation, Corbel's schools operate with a form of de facto segregation by overreferring African American students for special education and underreferring them for gifted and talented programs.

The racial inequities in bussing and referrals were among the reasons that a formal complaint was lodged against the Corbel school district in 1996 by Black community members and their independent counsel. Their claims of racial discrimination were supported by an investigation of the Corbel school district by the Office of Civil Rights (OCR). The complaint alleged systemic discrimination in student assignment and other issues. These concerns had been voiced for over 8 years but were not addressed until the community group threatened a lawsuit, which was followed by the OCR investigation. It was only then that the school board and district decided to meet and reach an agreement. A "controlled schools of choice" plan was agreed upon as a means to address the inequities in busing and student assignment.

The district began its implementation of schools of choice in its 11 elementary schools in the fall of 1998. This plan was designed to eliminate "racially identifiable schools" by giving parents a choice as to where they sent their children to school. Additionally, each school was required to maintain a number of African American students representing the African American student population of the district, which is $32 \%$. Each school was permitted to have between $15 \%$ and $49 \%$ (which is $+/-17 \%$ of the $32 \%$ ) African American students.

The Corbel context was racially charged because of the OCR report and the charges of discrimination in the district. This racial charge was felt in a number of different ways. First, the spirit of the schools-of-choice agreement reinforced the ideology that a majority of White students in a school was the ultimate goal by stating that Woodson must attract more White students. That the district had closed Woodson's doors to Black students further inscribes the ideology of White superiority because it functioned to limit the choices of Black families who wished to send their children to a school that served a majority of Black students. 
Second, the discourse of the "schools of choice" agreement reified the ideology that White is not a race. It stated that "no school will be racially identifiable" under the new plan. Because the new plan was designed to ensure that African American students constituted between 15\% and 49\% of each school's population, every school was to have a majority of White students. This White majority, however, did not render a school racially identifiable. Therefore, Whiteness was made invisible in this context. The district's discourse used the terms overrepresented and underrepresented solely in reference to African Americans. This discourse further obscured Whiteness as a category and created a situation in which Whiteness was not interrogated.

Third, the district's plan had no underlying theory about why discrimination in schools occurred in the first place, except the subtle suggestion that teachers acted in discriminatory ways. There was never any official mention of the Eurocentric curriculum or the fact that the legacy of forced bussing may have alienated the Black community from the schools. The implicit suggestion that teachers were the sole culprits for racial inequality made teachers wary about acknowledging race at all. Teachers were pressed to find some way to position themselves as valuable.

Finally, the Woodson School created a particular contextual factor. The Corbel community scapegoated the teachers at Woodson for years. They experienced the ancillary effects of institutional racism. Because Woodson was known as the "worst" school in the district, they were known as the "worst" teachers. The district and city had historically discriminated against Woodson's students by placing the students in the oldest building in the city for years; "dumping" on them the teachers whom no other school wanted; placing a disproportionate number of special education students in the building; and forcing them to begin school in an unfinished new building in 1998. The teachers, however, also felt the sting of that discrimination. By virtue of teaching the "forgotten children" of Corbel, the staff experienced the effects of racism as well. Given the district discourses about the dysfunctional students and teachers at Woodson, it was not surprising that teachers might engage in deficit discourse about students and families as a way to counter their representation as the root of the problem.

One of the privileges of Whiteness is that we can choose where to position ourselves; once you choose your position, who you are becomes defined around that. The teachers at Woodson had lost some of their White privilege of self-definition because they were unanimously positioned as "bad" teachers. However, as these cases will demonstrate, there are multiple ways of defining oneself as a good teacher of students of color in spite of the subtle ways that these roles may function to reify racism. 


\section{The Woodson School}

Woodson School was unique in a number of ways. First, it was one of two schools in the Corbel School District that moved into a new building for the 1998-1999 school year. The former building was the oldest school building in the district with limited space for Woodson's students. Second, it has been the only community school located in the Black community in the northeast section of town since Corbel desegregated its schools in the 1960s. Third, Woodson was the only school in the district whose population of African American students exceeded the number of White students, which means that it was the only school that had to turn away Black students who listed Woodson as their first-choice school. Finally, this school suffered from a number of administrative changes over the years, which contributed to its longstanding reputation as the worst school in the district.

The school was situated in the heart of the Black community near two busy intersections. There were two new playgrounds outside the school and a large grassy lawn, part of which held the Woodson school community garden. Two local community groups and four Woodson teachers and their classes jointly created and maintained this vegetable and flower garden.

At the time of this study, Woodson School served about 350 students, of whom about $72 \%$ were Black, $25 \%$ were White, and $3 \%$ were Latino, Asian American, or Native American. There were three classes on each grade level from kindergarten through Grade 2. The rest of the grades had two classes each. There was a $3 / 4$ bridge class and a 4/5 gifted and talented district class, which was the most racially diverse class in the school and contained the fewest number of Woodson walk-zone students. Over $80 \%$ of Woodson students qualified for free or reduced-price lunch. The students' scores on standardized reading and math tests had traditionally been the lowest in the district. The teacher attrition rate was also the highest in the Corbel district. Twenty-seven of the 35 professional staff members were White; Black personnel included the principal, one reading recovery teacher, four classroom teachers, and most of the classroom and lunch aides. There are two male teachers on the staff.

\section{METHODOLOGY, DATA COLLEGTION, AND ANALYSIS}

I came to know Woodson School the year before the move to the new building. Over the course of the next 3 years, I engaged in an ethnographic research study of the Woodson School. I conducted a total of 42 interviews with 27 teachers, worked regularly in eight teachers' classrooms, participated in schoolwide events, attended many social functions with the staff, and facilitated a seminar on teaching antiracism (STAR) during the 1999 
spring semester for 24 professional staff members, six of whom were people of color.

As I began to interview staff members at Woodson, I quickly learned that the teachers held low expectations for students, saw the families as dysfunctional, and saw themselves as victims of the most difficult work environment in the district. During this time, I was working with nine teachers on integrating a community garden project and a community arts project into their curriculum. By my second year at Woodson, I was spending 10 hours each week participating in the community gardening and art classrooms, meeting with teachers, attending meetings, and interviewing staff. My field notes initially focused on general observations and became more focused as I began to get a sense of the school culture. In my initial interviews, I was interested in understanding how teachers understood their role in the school, how they characterized students and families, and how they understood the race politics of the district.

Data collected from the 22 individual interviews with staff members, two focus groups with staff members, and numerous ethnographic observations and field notes during my first year with the staff revealed a staff culture that participated in and supported color-blind and racist discourse and practices. The following year, I discussed with the school principal and some of the teachers the idea of starting a discussion group about race and racism at Woodson. The principal and the staff members were in favor of the idea. That spring, we began the seminar with 27 staff members, three of whom dropped out during the first few weeks of the seminar. The group read articles that they had selected and then discussed them each week, first in a large group and then in three small groups. The seminar was focused on examining race in the context of the Woodson School and how racism in general was perpetuated in schools and society. Each of the staff members participated voluntarily and received three free graduate course credits. This was an on-site seminar to build collaboration and inquiry with teachers from one school, thereby creating opportunities for teachers to support each other in identifying racist school practices and create a culture (or community) of teachers working toward improving their practice (Gutierrez, 1999).

Each of the 15 seminar sessions was taped. This resulted in four audiotapes for each session, one for the large group and one for each of the three small groups. I listened to the seminar tapes repeatedly and selectively transcribed them based on the information that they revealed. Each of the seminar participants maintained a weekly journal that they allowed me to photocopy for data analysis. Following the seminar, I conducted 25 more interviews with professional staff members and continued to participate in school activities and teachers' classrooms on a regular basis.

For this study, I selected four teachers who were participants in the seminar, in whose classrooms I had visited on at least five occasions and 
whom I had interviewed at least twice. Pam is a White special education teacher with 35 years of experience, and over 15 years at Woodson. Sylvia, who left her second-grade teaching position at Woodson after her third year, was born in Ecuador but was adopted by a White family when she was 6 years old. She identifies as White in spite of her Ecuadorian heritage. Carmen is a White first-grade teacher who had been teaching for 6 years, the first 3 on a Navajo reservation in the Southwestern United States. And Maizie is a White fifth-grade teacher in her third year of teaching who had taken three professional development courses dealing with racism.

I selected these four teachers because of the variety of ways that they saw themselves as teachers of students of color. Pam, Carmen, and Maizie each clearly identified themselves as very good teachers of students of color and described their roles in positive terms. Sylvia was selected to demonstrate the ways that a person of color can be subsumed by Whiteness and participate in White racism in schools. These teachers were not selected as archetypes or as examples of the only roles that White teachers could possibly adopt; rather, they represent four examples of the myriad ways that teachers can define their roles positively and may also unwittingly perpetuate racism. They were also chosen to highlight the ways that they both practiced and negated some features of what is described as culturally relevant teaching.

To analyze the data, I first read each transcript from interviews with these four teachers: two interviews each with Pam, Sylvia, and Carmen, and three interviews with Maizie. I began to notice that they each continued to name themselves as teachers in very specific ways. As such, I went through the interview, seminar session, and journal data carefully to identify all the roles that they named for themselves as teachers. I first looked for words that they used to describe themselves as teachers of students of color (e.g., helper, benefactor, White, Hispanic, role model, cultural interpreter, activist, radical) and determined which ones they each used most frequently. I then identified stories within the transcripts that supported the roles that they assigned themselves. Finally, I looked for evidence in my field notes for ways that the teachers acted out the roles that they named themselves. I use the term central metaphor to describe the primary roles that each teacher identified. These metaphors were not the only ones used by teachers, but I name them as central because they were the ones most frequently identified and had the most supporting evidence in terms of the teachers' stories and their actions in the classroom. These metaphors were also those most closely linked to their understanding of what they saw as their unique role as teachers of Black students.

According to Lakoff and Johnson (1980), metaphor is more than a feature of language alone; it is pervasive in the thoughts and actions of everyday life. They asserted that "our ordinary conceptual system in terms of which we both think and act is fundamentally metaphorical in nature" (p. 3). The central metaphors identified by the four teachers seemed to 
direct their behaviors and beliefs in ways that had material effects for students and for themselves as teachers. I identified these metaphors as an analytic to understand most closely how they understood themselves. I confirmed with each of the teachers that they also saw this metaphor as central to how they defined themselves as teachers.

Through constant comparative data analysis (Bogdan \& Biklen, 1992), I was able to identify the common and contextually regulated discourses and practices of each teacher. I looked at each teacher's practice and beliefs in relation to what the educational research tells us about successful teachers of African American students. By using critical qualitative and interpretive data analysis (Denzin, 1994; Denzin \& Lincoln, 1994), I was able to see how these teachers sometimes operated in ways that supported a racist status quo, and the ways that they saw their practice as working against racism.

As a young White teacher in an African American community in Brooklyn, New York, my personal struggle to define my role as a White antiracist teacher was hard fought. My own identity is fluid and still developing. This acknowledgment is related to the tension that I feel as I represent the experience of Pam, Sylvia, Carmen, and Maizie. The research process requires me to represent these teachers and analyze their words from a critical stance. However, this is merely a representation of these teachers as they were at a moment in time. In life, unlike the written word, people are fluid and changing. Therefore, these representations must be read as partial and incomplete, merely snapshots of teachers that are useful to understanding the difficult task of becoming a successful White teacher of students of color.

\section{THE CASES}

\section{Pam}

Pam was a teacher for 34 years. She moved throughout the Midwest and finally arrived at the Woodson School in 1983. She has been there ever since as the LD (learning disabilities) teacher. In her work, she was involved in the identification and classification of students for special education services. She provided a pullout program for those students who were labeled with learning disabilities but who were included in the regular classroom for most of the day. Prior to holding this position, she served as the teacher for the educationally handicapped in the three junior high schools in Corbel. Before that, she taught middle school language arts. District personnel thought that Pam's skills would be useful at Woodson School "because of the large numbers of problems at the school" and asked Pam to work there. Pam was active in the school's parent-teacher association (PTA) and was also involved in an action research group run by a uni- 
versity professor. She was very willing to be involved in professional development activities and was often the first to volunteer to organize schoolwide activities.

A good teacher of Black students is a helper. Pam's central metaphor for herself as a teacher was that of a helper or benefactor. She built her role as a teacher of students of color on the idea that she was there to help students and their families. Pam described herself in the following ways:

I am just here to help kids, but I find I spend a lot of time helping families too.

I guess students just need someone to care for them and give them some of the attention that they deserve. [This was in response to a question about what she felt she did differently as a teacher of students of color.]

A lot of these families don't have much, and they come to rely on me as a kind of benefactor or patron because I will help them, but they need to earn it and deserve it.

These children have so little that you need to give them things. You need to bring in things like gloves, hats, candy-just so they know that you care.

Pam told stories to illustrate how helpful and successful she was with Black children. She told a story about one family who initially assumed that she was racist because she was White, but who later came to see her as a valuable teacher:

My first year teaching ... in this school where everyone is just getting along really well-no problems. Then there was one kid and I said, "Get in there." And he said, "you're just prejudiced because you're White." Well, I moved to Corbel 5 years later and met the same family and it's like I'm God's greatest gift to Black children because you know I'm caring and I worry about them. And I thought, "I can't be the same person to the same family that I dealt with 5 years ago."

Pam frequently used terms such as helper, benefactor, and patron to describe herself, and the stories she told often had a similar theme. For example, while describing one of her class trips, she told me that her husband made bologna sandwiches for all the students and met them at the museum: "I mean the kids were all just so excited to be getting these bologna sandwiches. They all like bologna. Some of them even ate five or six of them. I think they knew that I was there to help them and this was one of the things I could do for them."

As a testament to how helpful she was to families, Pam also told me about helping a parent who was in financial difficulty by assisting her in hocking her stereo. She described it in this way:

Well, one time, a parent came to me in trouble, money trouble. I told her I'd help her but I wasn't going to just give her anything and I told her she would have to help herself. So, I went with her to hock the stereo. I held the slip, you know. This way, she couldn't get it back unless she paid off every penny. I checked up on her 
every week and finally she had paid it off and I got her stereo back. She was so grateful to me because she knew that I had helped her. I mean I was tough on her though, I wasn't just going to give her something. That's not what these people need.

In addition to her metaphor for her teaching as that of benefactor, Pam also saw herself as a benefactor to people who are discriminated against in the broader society. She was a watchdog for discriminatory acts and was willing to step in when the situation presented itself. She told the following story during one seminar session while her small group was discussing racism:

In a small town outside of Louisville, we were having dinner and there was only one Black person; and to the waitress he didn't exist. Twenty people or so in line, he was right in the center. A big man, there is no way you could avoid him, he was right there and you know he had a big booming voice and they totally ignored him. So we're getting ready to leave and everybody goes out, and I said, "Hang on just a minute, I'll be right there." So they went on out to the car, and I stopped and I said, "Excuse me, could I have the manager because I have a complaint." And I said, "Do you have a problem seeing that human being back there? Could you not see him? Surely you had to see him because he stood out." I left the restaurant and I said to my husband, "Hit the gas. Let's get out of here." But it does happen. I'm not gonna stand back there and not say something. I couldn't let it go unnoticed. I'm very conscious of the difference in color.

Hidden racism in the helper metaphor. On the surface, the idea that a teacher sees herself as a helper of her students of color and their families seems like a good thing, or at worst innocuous. However, Pam's concept of a helper had material effects for her students that perpetuated a racist status quo. A central aspect of her metaphor was that she saw students and their families as quite needy and in some ways incapable. As such, she helped them with bologna sandwiches and by holding the ticket from the hock shop because she did not believe that the students and the families could take are of themselves. Central among teachers identified as culturally relevant is a respect for and value of the students and their home communities (Gay, 2000). Pam's actions, while helpful, demonstrated a sense of superiority over her students and their families. This sense that students of color couldn't do for themselves was also evident in how she enacted her role as helper in the classroom.

Pam states that in her role as a special education teacher, she rarely tries to facilitate students getting out of special education, even when their goals have been met or exceeded, because she is convinced that they will always need special education services, and declassifying them would be an educational injustice: "I don't try to declassify many students because, let's face it, they need the help. Even if they have made great progress, they still could use the help. And I am of the belief that once you are LD, you are always LD.” 
Pam viewed special education referral, testing, and service delivery practices as race neutral. She did not feel that a disproportionate number of students of color are designated as requiring special education:

Personally I don't think that a disproportionate number of minority children are being forced into special education. I personally do not feel that. You know, if you are an EMH (Efficient Markets Hypothesis) person, it doesn't matter what color your skin is; it's what you have to work with. So, you know, it's a shame that it's come to that.

Pam's reluctance to declassify students labeled as having special needs, coupled with her refusal to recognize overrepresentation of students of color in special education, could potentially make her a poor advocate for students of color and perpetuate the system of racism that puts so many students of color in special education to begin with.

In addition, Pam's insistence that students with learning disabilities would always need help allowed her to create lessons that were designed to help them but that could function to underprepare them for academic success. For example, during one writing lesson with a pullout group of three fourth-grade students, all of whom were Black, Pam taught the students how to use the ellipsis marks in their writing. She had posted on a piece of chart paper the following three sentences:

John thought ... and then thought some more.

I am wondering ...

My mother, my brother and I . . . at the store.

Pam explained to the students that the three dots were ellipsis marks used to substitute for omitted text. She asked students what words might have been where the ellipsis marks were. The students generated responses, and she then asked them to write sentences and omit words using the ellipsis. At the end of the lesson, she explained to students, "Now, when your teacher asks you to write a sentence, you can write fewer words by using an ellipsis. You can tell your teacher that I said it was a real sentence." After the lesson, Pam explained to me that because these students had difficulty writing, she thought this would make their life easier. Clearly, her lesson was well intentioned and reflects her role as helper, but it did little to prepare these fourth graders as writers. Lessons like these fail to tap into the high expectations for academic success that characterize successful teachers of students of color identified by educational researchers.

Is seeing racism central to being a good teacher of students of color? Pam's growing consciousness about the existence of race became evident during the course of this research. In her early interviews, she asserted that she didn't see color. Over time, she began to tell stories like the ones 
highlighted above. Seeing color fit well with her primary role as a helpersomeone invested in doing good deeds for less-fortunate people. It did not, however, translate into a broader recognition of the ways that this kind of helping on the part of White people might serve to perpetuate patronizing forms of racism grounded in historic hierarchical race relationships.

Pam's feelings about herself as a benefactor to poor children and to people of color indicated that she identified one aspect of racism-that people of color are less privileged and are sometimes treated prejudicially-but she did not see this as part of a system of White privilege and dominance. For Pam, her own role as a White benefactor acted as proof that White racism was not systemic. She once stated during a seminar, "If racism was such a big problem, there wouldn't be any teachers in this school, would there?"

After a semester of discussing race, Pam still saw racism as something that people of color need to "overcome" and stop focusing on. She stated,

If they realize the value of an education then they can overcome it [racism]. But, you know, I'm not saying it doesn't exist. I'm just saying that I don't think it needs to be, you know, every single day. "This is a racist society; this is a racist society." I'm one of these that kind of believes, if there's a problem, you try to fix that problem and get on with your life. Don't dwell on it.

Pam's beliefs about racism are in sharp contrast to teachers identified as culturally relevant, who recognize institutional racism as central in the lives of their students and understand their work as a fight against racial injustice (Ladson-Billings, 1994).

\section{Sylvia}

I knew Sylvia during her first 2 years as a teacher, after which she left the school to take a job at school in a White suburb of a large nearby city. During her 2 years at Woodson, Sylvia taught second grade. Sylvia's personal history seemed to have significantly influenced her understanding of race. Sylvia's given name was Spanish, but she went by an Anglicized version. She was born in South America and adopted at the age of 6 by a White American family following the death of her biological parents. Sylvia was the youngest of eight children, all of whom were adopted by the same family. Sylvia did not self-identify as Latina, but her older siblings did. Sylvia considered herself White and had no memory of her life in South America. Sylvia often mentioned that she did not think of herself as Hispanic and had "never felt like people treated [her] unfairly." 
A good teacher of students of color is assimilated. During the course of this research, Sylvia brought up her Latina heritage frequently to counter the existence of racism. She rejected the existence of racism because she was born Latina and had never felt discrimination. During one seminar session, she said, "I am feeling guilty now because I don't feel like I am disadvantaged and technically I am Hispanic, but I don't see myself that way. Maybe that could be good for our students too-to stop seeing themselves as minorities."

Sylvia's central metaphor for herself was as an assimilated White person who could possibly be a role model for students of color who could choose to be White, as she had. She came to see herself as this type of White role model over the course of the time I worked with her. She made the following comments in journal entries and interviews:

I think that having grown up in a White family, but being Hispanic has allowed me to learn a lot about how minorities should act. I guess I could be a good role model for my students as someone who is Hispanic, but doesn't see herself as that.

Basically, I feel White. I mean I was born Hispanic, but I am White. I know I am light skinned, but I think almost everyone can do what I have done.

I think that I have been successful in my life because I never considered myself Hispanic. I mean I never let that hold me back because I never saw myself that way. Two of my [adopted] sisters are Korean and we are the ones that see ourselves as White.

I know my students could be successful, but they are limited by some of the things that go on in their families. I was lucky to have White parents.

Many of Sylvia's stories also related to how she had assimilated herself into Whiteness. She described how her older biological sibling referred to her as "gringa" and made fun of her for not speaking Spanish. She stated that this did not bother her because she knew that she would be more successful than they.

I don't think it's wrong for me not to be Hispanic. One of my older sisters has a problem with me being White. She calls me "gringa," which is like a White girl ... they all think it's kind of like disrespect to my parents ... I just don't remember them. But it's probably better that I don't. I mean, I like who I am. I know I will be better off this way.

Sylvia also told stories in which she was clear to affiliate herself with White teachers and identified whatever problems students were having as part of their failure to assimilate:

I don't really feel like the parents are respectful. I know one of my students, who I talk about a lot. She is really difficult. I don't get the respect from her parents simply because I feel she knows I'm not African American. And she doesn't feel like she can relate to me. And I feel like the child disrespects me too simply because 
I'm not African American. So it is difficult to get the same respect from the African Americans.

Their social attitudes aren't well developed. Outside of the school they have to learn to be tough because of the neighborhood that they are in. They see a lot of this toughness at home. So when they come to school they don't know how to solve their problems ... they just want to hit somebody, [they] just want to yell and scream because that's what they do at home. It is not like a White middle-class community.

Racism embedded in the assimilated White metaphor. Sylvia's role as an assimilated White person allowed her to see herself as a successful person. She hoped that her students would learn from her example and begin to act more like White people. Sylvia's role perpetuated racism in a number of ways. For example, being White was so important to who Sylvia was that she expressed prejudice against Latina and Latino people. She said the following during our final interview:

Sylvia: It's so weird for me because I don't have that connection to Hispanics like I should. And I feel like I'm the exception [chuckling]. I am not a Hispanic! Unless I want to be.

Nora: Right. You actively sort of reject that label for yourself?

Sylvia: I think I do. Because I don't like Mexicans, but especially males. They're so macho and they're so egotistical that it annoys me. So I can't stand them and I know I can never date one. And then the girls have their stereotypical ways too. Except Audie [one of the Latina undergraduates who worked in Sylvia's class on the gardening project], she didn't come across that way so I had no problems with her. And, but still, I didn't feel like I bonded with her like, we were never Hispanic together, you know?

Sylvia also had low expectations for her students. For example, when Sylvia spoke about why she felt that she couldn't do creative teaching with her students, she placed the problem squarely within the students' families, community, and race. Sylvia did not take responsibility for the problems she was having in the classroom:

I would like to do creative, hands-on stuff, but these kids just can't handle it. If I try to let them work in groups it is not good.

I make things a lot simpler for my kids than you'd see in a regular White class, or middle-class school. I try and do most everything with the class unless it's tests. Then I'll just read it and let them give me the answer, but I basically spoon feed them everything and go through everything with them because they just don't like to do things independently. It's too hard for them. They get too flustered by it.

By contrasting her work with what you would see in a "regular White class," Sylvia made clear that her pedagogy was influenced by the race of her students. Unlike teachers who have been identified as culturally relevant teachers, Sylvia held low expectations for her students as a result of their race. As a self-identified assimilated White teacher, it was easy to locate 
the problems within students and families. Sylvia described her students and their families using what are considered White code words for Blackness, such as violent, dysfunctional, uncaring, and poor (Giroux, 1997; Ladson-Billings, 1998). She also used these words as general descriptors of the local Black community.

Sylvia's codified language often resulted in exaggerations of the Woodson community. These comments function to reify how different and separate she is from the Woodson community. For example, a group of us were informally discussing the content of a mural that Maizie's class was working on. Maizie suggested that the mural should represent the life histories of people who live in the Woodson community. Sylvia's response was, "Make sure you include a nice scene of a drive-by shooting."

This comment was an exaggeration of the crime in the Woodson neighborhood. The crime rate in Corbel is actually very low. This exaggeration of violence can be a way to code language about race without mentioning race (Ladson-Billings, 1998).

This discourse fits with the images of Black and Latina/Latino communities that are perpetuated through the media. White people often use coded language to discuss communities of color and reinforce the superiority of Whiteness. This "White talk" functions to create a distinction between Whites and people of color and is used to solidify one's membership in Whiteness (Sleeter, 1996). This kind of language defines the lines between groups of people and can function as a discursive indicator of the speaker's racial affiliations. Because "language is community" (Morrison, 1998, p. 8), this discourse serves an important function for Sylvia, who chose to be a member of the White community.

The material and potentially racist effects of Sylvia's role as an assimilated White teacher included feelings of prejudice toward students of Latina/Latino heritage, a lowering of expectations for her students with a reliance on teacher-led work, and an overt use of racially coded language that reifies Whiteness as the norm. These actions can function to harm students of color and limit their opportunities for academic success. In contrast, culturally relevant teachers are identified as working against prejudice, holding high expectations and ensuring academic excellence, and having positive views about and relationships with their students' home communities (Gay, 2000; Ladson-Billings, 1994).

\section{Carmen}

Carmen had been a teacher for 6 years. She grew up in a White suburb of a large Midwestern city and attended the university located in Corbel as an undergraduate. Carmen had two master's degrees, one in reading and one in special education, from the same university. Carmen spent her first 3 years teaching on a Navajo reservation in the American Southwest. She was 
at Woodson for the 3 years of this program of research. She taught first grade for her first 2 years at Woodson and then began working half time as the reading recovery teacher. She also taught migrant students from Mexico during the summer months.

A good teacher of students of color is an intercultural communicator. Carmen placed an emphasis on culture and her own understanding of it as central to what made her an effective teacher of her students. The central metaphor she used for her teaching is that of intercultural communicator. She described herself in the following ways:

I am very interested in culture and I guess I am good at becoming part of a different cultural group.

I am like a chameleon when it comes to culture, I try to adapt to the norms of the people I am with.

I can easily communicate with people from different cultures because I learn how they act and I act like them too.

Carmen self-consciously adopted the cultural norms of the communities in which she worked. In discussing the effects of race and racism, Carmen drew a link to a particular group's cultural norms. For example, when discussing her transition from teaching Navajo students to African American students, she talked about the way that she had to adapt her language usage. She said that her speech had become slow and deliberate because that was the way the Navajos talked. When she came to Woodson, she was still talking like that, and her students "were like, 'Lady, what are you saying?" She then adopted their speech patterns to use in the classroom.

I mean it's really interesting the way you teach Navajo kids, the way you teach African American kids, and the way you teach you know, children from Mexico. It's so different. You have to teach differently, the things that you say and the way that you are. You really need to be aware of that when you teach because what I would say to the Navajo kids would never work with the African American kids. And what I say to the African American kids makes the migrant kids cry.

Carmen's understanding of cultural differences indicated that she saw herself as able to move easily from one culture to the next. She said that she was very interested in different cultures and understood racial differences through a cultural framework.

Carmen stated that some people think that their culture is better than others, but she did not see things that way. She saw all cultures as being good and valuable. For Carmen, the important things to notice were cultural norms of the group with which you work and to respect those norms even if they were different from your own. She also thought that it was important to celebrate your own culture if you are White. 
Just watch the people and really respect who they are. A lot of people come in trying to save people and trying to fix people. And they're not broken and they don't need to be saved. You know they need to be respected, and I don't think a lot of teachers see that. I think they see them either as these poor Black children, these poor Navajo children, or all these cruddy, crappy families. They all just generalize too much. And, you know, I don't think a lot of teachers can move between the worlds, because they don't have the ability to go outside their own culture and say, I have a culture, now let's look at, see what another culture can be like. 'Cause when I first went out to New Mexico, I didn't think that Whites had culture; I just thought it was the culture; everybody's White, everyone is kind of White, you know? And then when I got out there, I realized what it meant to be White.

Carmen described her experience working with the Navajos as being difficult at first. She described how the Navajo teachers did not talk to her or accept her. She did not frame this as a form of reverse racism, as Pam and Sylvia might have, but rather as a characteristic of Navajo culture:

I was new and I was White and they didn't know me. And I sat through the first meeting all by myself. And my principal finally came in and said, "We have a new teacher here somewhere? Oh, there she is." And I ran home crying to my husband. I was like, "Oh my god, they were so mean to me." But I later realized it was just because that was their culture. They don't speak to people they don't know because they consider it taboo. If you have a negative quality about you, like if you are mean, or do naughty things, or are mean to your kids, if I talk to you without knowing you then those things could transfer to me.

Carmen's willingness to learn cultural traditions and her efforts to be nonjudgmental about other cultures led to the establishment of positive relationships with the parents of students in her class. Carmen always had the highest number of parents attending parent-teacher conferences, and on one occasion, she held a "literacy night" during which all 26 of her first graders came to school and made a poster and story with a member of their family. Given the reputation among the Woodson staff that parents were unsupportive and uninterested, this event indicated a real connection between Carmen and her students' families. Carmen was proud of the participation that she was able to generate. Her positive relationships with parents and willingness to observe and learn about other cultures were very connected. She rarely participated in deficit discourse about students and families, she was respectful and interested in the cultural norms of different groups, and she integrated information about many cultures into her classroom.

Hidden forms of racism in the intercultural communicator metaphor. Carmen's role as an intercultural communicator served her well and had some clear benefits for her students, most notably her positive relationships with their families and the families' increased willingness to participate in schoolsponsored events. These aspects of her role as a White teacher who assimilated to the cultural norms of the community in which she was working 
seemed to operate against racism. Indeed, in her research describing the practices and attitudes of eight teachers whom she identified as culturally relevant for African American students, Ladson-Billings (1994) noted that the White teachers had adopted a worldview similar to that of their Black students. What was not clear was whether Carmen actually adopted the worldview of her students and their community or simply adopted their cultural behaviors. This difference first became salient to me during an informal conversation with Carmen and an African American doctoral student colleague of mine. Carmen was describing how she changed her behavior when she arrived at Woodson. When she described the cultural norms of Native Americans and African Americans, she mimicked the speech of both Navajo and African American people. My colleague was visibly offended by the mimicry of Black speech patterns and later commented to me how typical it was for a White person to believe that she could simply colonize the behavior of people of color without realizing how racist it is to sit there and imitate people while pretending she was just like them. My friend's point was that Carmen's cultural communication was not genuine; she simply studied and learned how to imitate behavior without adopting a worldview. This imitation of speech and cultural norms was neutral and inoffensive in Carmen's thinking.

Carmen saw culture as depoliticized and did not view her actions as White appropriation and essentialization of the norms of marginalized cultural groups. Carmen was able to "see" White culture because of its contrast with Navajo culture. Her understanding of White culture is that it is equal to that of other cultures, not how it may be politicized and represented as better than the cultures of her students, or how her own Whiteness may mediate her relationships with other cultural groups. For example, when Carmen described the obstacles faced by her students, Carmen focused on poverty and did not connect poverty to racism or White dominance:

It's not race and it's not culture; it's poverty. That's the blank issue 'cause you can be White, you can be Black, Native American, Mexican, if you have poverty in your life, that's going to make the difference for a lot of families. A lot of families can be poor and they can still work through it, but if poverty plays an issue with how much time parents are at home, how much they have done traveling and seeing the world and going places and books that they can buy. So I think poverty and exposure are the things that they have that are obstacles.

Much like her view of culture, Carmen saw curriculum as neutral as well. Carmen saw culture as important for interpersonal relationships, but did not believe that one culture should be (or is) emphasized in a school setting. Carmen stated that it is detrimental to students to use an alternative curriculum that emphasizes Black culture:

You teach them how to read. You know, so that was my job. And that is the key that I think that we're missing here. So many people are emphasizing culture here at 
school. I wasn't really taught culture in school. You know, I went to a mainly White school. And I'm not saying that there shouldn't be any culture taught at school; we did themes and units where we studied many cultures. I am $100 \%$ for that, but to just teach the dominant culture of that school, at that school, to me it seems odd, you know, because you're never going to just coexist in this little bubble with just your culture. You need to learn how to exist in a lot of different cultures because there's a lot of different people out there.

Although Carmen was aware that culture is important for teachers to learn about, she saw the standard U.S. curriculum as race neutral. She did not recognize, like culturally relevant teachers, that the Eurocentric curriculum of the typical American school reinforces White culture as the norm. Critical multicultural educators have found that school success is often dependent on one's ability to conform to and assimilate into dominant White ways of being (Fine, 1991; Klug \& Whitfield, 2003; Ladson-Billings, 1994; McCarthy, 1993). In fact, schools typically expect students to conform to and celebrate White American culture and function to marginalize the learning styles, histories, strengths, and knowledge of other cultures. In Carmen's view, however, school practices and curricula are basically as they should be, and teachers who come from a different cultural background from their students simply need to learn how to adopt some of the students' communication styles. Her analysis did not include how power and cultures intersect.

Carmen's teaching practices could certainly be empowering for her students. However, her focus on culture only as a form of communication perhaps blinded her to other potentially empowering pedagogical forms. Because of Carmen's uncritical approach to culture and to the relationship between culture and power, she was unable to help her students look critically at their social word. She rarely introduced alternative perspectives of history or community problems.

Growing to see racism as something larger than cultural difference. Over time, as Carmen reflected on her participation in this 3-year study, she indicated that she had expanded her understanding of racism. In her view that cultures were merely different sets of behaviors that were basically all equal, she had not been able to see how culture was related to power and racism. As such, her view of racism meant nothing more than outright bigotry, and she failed to see how her students and their families might be victims of racism. Over time, however, Carmen began to express a broader understanding of racism as related to cultural power that is held by culturally relevant teachers. In our final interview, she even suggested that she might participate in racism:

At first you think of racists and you think of bigots. I mean that's what you initially think of, but then throughout the class you kind of started picking up on the subtleties of ways that people, and myself, do things that could be considered racist. You know, whether they're meant to be racist or not, there are subtleties to it that I was unaware of. I guess that just opened things up and made the definition of 
racism bigger than what it had been. I mean, the idea that White culture is privileged is new to me.

Carmen did not articulate exactly what she meant by her expanded definition of racism or exactly how her understanding of racism had changed, but she was beginning to demonstrate that her role of intercultural communicator might need to be expanded to incorporate an understanding of Whiteness as a construct that can disempower people of color.

\section{Maizie}

Maizie grew up in a small all-White Midwestern town. She began her teaching career at Woodson during the first year that I began my research there, so I was able to work with her during her first 3 years as a teacher. She taught fourth grade during her first year and followed her students up to fifth grade for her second year. In her third year, she continued to teach fifth grade. After college, Maizie had trouble finding a teaching job, so she took a position as an educator on a grant project. For 2 years, she worked as a liaison between teachers and the state museum and a state zoo. The goal of the project was to get teachers to use outside resources in their classrooms "to open up the doors and walls of the classroom." This experience also exposed her to the numerous ways that educators can use technology in the classroom. Maizie knew that she eventually wanted to get into the classroom. She took the job at Woodson mainly because jobs were scarce at the time.

A good teacher of students of color is a radical. Over the course of the 3 years we worked together, Maizie's central metaphor for herself as a teacher of students of color developed into her role as a radical. However, when I first met Maizie in the fall of 1997, she was a frustrated new teacher ready to quit. She said that she originally felt that she could "handle working at Woodson" because she had student taught in a school that serves a "similar population of students, only they were mostly White instead of African American. They had similar problems though." Maizie said that she became a teacher to help "improve students' self-esteem and help them learn that they can be successful."

At that time, Maizie felt that students' self-esteem was low and seemed to frame that self-esteem as a deficit inherent in the students:

Well, I think their low self-esteem. That's a big problem. They don't feel like they can take a risk when it comes to looking at a problem in a different way or looking at something new. I mean I'm sure that has to do a lot with them trying things and not being able to do them so they feel like they can't do anything. 
In addition to seeing her students as being somewhat deficient, Maizie was like her colleagues in that she did not see racism as something that was significant in the school. She also defined racism as identifiable solely through individual acts of prejudice:

Because I've seen kids of both races who ... I mean they're really good kids who are African American who wouldn't cause anybody any trouble, and there are really good kids who are White. And it's the same with kids who are troublemakers, I mean they're Black and White. So I don't really see how ... I can see how maybe more African American kids get sent to the PAC room [a disciplinary room called the positive action center] because there are more African American kids in the school.

Maizie's analysis was based solely on whether teachers discriminated in terms of discipline. She did not, at that time, see racism as broader than individual acts of discrimination. She also understood students' behavior as being easily categorized as "good" and "bad." There was no complexity in her analysis of why a child might behave "badly."

In spite of her deficit language of self-esteem and her categorization of students as "good and bad," Maizie was an advocate for students. Maizie noticed that other teachers in the school spoke negatively about students. She was the only White teacher who consistently identified in-school obstacles to students' achievement and avoided much of the discourse of blaming the victim (Ryan, 1976). During her first interview in the fall of 1997, Maizie said,

One of the obstacles that students face from inside of the school is that some teachers come down really hard on them for behaviors that really aren't that crazy. I mean, kids need to talk during lunch. So when teachers come down hard on my kids for talking, or they don't treat my kids with respect... I've had some teachers talk to my kids like they are stupid-it's so frustrating to me, because no one should be doing that. They are here to learn, not to be told how stupid they are and how much they can't do.

These critiques of her colleagues were unique. The other teachers all identified obstacles that related to the students' home life, family, culture, or to the students themselves (Irvine \& York, 1993), but Maizie focused on what she saw happening at the school.

Over time, as her beliefs about students, her view of herself as a teacher, and her understanding of race and racism changed, she came to define herself as a radical. She made statements such as the following:

Compared to some other teachers, I look pretty good. I'm a radical, I guess.

I mean, am I a radical for addressing racism with my kids?

I know that I was apprehensive about bringing up race in the class, it seemed sort of radical to me.

I guess in some ways I have always been different-a radical, an activist, and all that. 
I know that most teachers don't even think about racism and how what they do and talk about affects their kids-that makes me really different, I guess.

Maizie's view of herself as a radical was linked to her commitment to democratic ideals. Maizie was committed to dialogic teaching and learning and worked to take a critical/political point of view with her students. She was very committed to listening to her students and considering their opinions. During our third formal interview, I mentioned to Maizie that when I was a teacher, I thought I was too concerned with efficiency and getting things done. In response, she described her way of doing things:

It's totally not efficient, but to me it brings out something that's more important than just getting something done.... I don't think it's good for them to have that much freedom. But I think they need to be able to voice their opinion and we still talk about things in class like rules and why we do certain things and I let them know I don't want them to do things just because I tell them to.

Maizie was on a constant quest for knowledge and demonstrated a willingness to see things differently. She routinely interrogated her practice in light of new information. She saw life as a learning process, a philosophy that transferred to her teaching as well: "I really believe that the point of being here is to kind of progress and get to a higher level of understanding, you know, what it means to be a human being, why we're here."

During the time we worked together, Maizie took three classes on race and racism. She was constantly interrogating her teaching and her own understanding of race and racism. She spent a lot of time reading professional literature and asked many people to come to her fifth-grade classroom to observe and participate. Since she first came to Woodson, Maizie was integrally involved in a community/school project through which her class worked with university students and community groups on community arts projects. She also worked with a graduate student in education for a full year to develop constructivist science teaching methods, and she was involved in a literature discussion project with another professor. This made for a lot of classroom activity, which Maizie felt helped her learn to be a better teacher and prepare her students for dealing with many different people.

Maizie saw herself as different from other teachers too in that she would break a teaching taboo and sometimes challenge other teachers about how they talked to students. Within these challenges, she determined that the low self-esteem that she had previously identified was brought on by the negativity of staff members in the school. She said,

I know that part of the problem is the lunchtime thing, but the other part of the problem that I think we need to discuss is that fact of how people react when they don't feel good. And I think we're making kids feel bad about who they are and 
the only way they can feel good is to at least put somebody else down, either by their words or by fighting with them. It, to me, shows that kids do not feel good about who they are being at this place.

Maizie identified the negative ways that teachers spoke to their students as being racist. She associated being color-blind with being able to ignore our own racism and recognized the ways that she as a White teacher still engages in color-blind, racist practices. She shared a story about herself to illustrate her point. She said that she sent a child to the office for rolling his eyes:

This is something I would never do, normally. But there was a new kid in the class, and I didn't want him to get the idea that doing that was okay. And Yolanda [the principal] said, "Would you have done the same thing if your new student were a girl?" I appreciate her telling me what she wanted to say without getting really confrontational about it. And I think she probably was also thinking, "Would you have done that if your new student was White?" And I thought about that and I don't think I would have. So I know that there are things that I wouldn't have even thought about.

This kind of self-reflection and willingness to learn from others is characteristic of Maizie's role as a radical. Few teachers were able to identify ways that they participated in racism. Maizie's public admission that she may have done something discriminatory was a challenge to the rest of the staff to do the same before they decided to interpret students' behaviors as "good" or "bad."

In addition to developing a critique of her own and other teachers' discrimination, Maizie developed a critique of the school system as well. She began to see the effects of institutional racism on her students. She often cited that students of color and their families are routinely represented as dysfunctional. In addition to seeing that students of color are pathologized by the school system, she identified the societal messages that are produced about different races in the media. As she began to see how her Whiteness has constructed and constricted her worldview, Maizie's sense of her own responsibility for working toward social justice began to change: "And I think it's pretty mind-blowing for somebody to think that to change how they view that, how they view themselves, how they view being White in our society because it changes your way of thinking on everything that's around you!"

Maizie began to change her practice as well. One of the first things she did was decide to make contact with the families of her students over the summer. Maizie had stated in the past that she wanted to get to know her students' families better, but she felt that her time was limited with all of the things she was doing. But during the summer before her third year of teaching, Maizie went about visiting the families of the students who were to be in her class: 
I visited about two thirds of my students' families over the summer. I want to build a positive relationship with the parents. I wanted them to feel comfortable with me, and I also wanted to get some ideas and suggestions from them about how to set things up in the classroom. To get their different ideas, things that teachers had done with their kids in the past and they liked or didn't like. It was just nice to see and hear about kids from people who know them so well and care about them so much and it was really a way for me to start to get to know the kids a little better.

Maizie's description of her visits with the parents indicates that she saw them as a resource that she can use to learn more about her students.

Maizie's initial forays into working with parents, valuing their knowledge, and creating a classroom climate in which students were free to explore critical questions about race indicated that she was actively engaged in working to become a culturally and politically relevant teacher (Beauboeuf-Lafontant, 1999; Ladson-Billings, 1994). Seeing herself as a radical helped her to move in this direction. Prior to investigating race, Maizie viewed herself as a learner. She saw that teachers must continue to learn and grow and listen to their students, but as she investigated race, she began to act upon what she had learned.

Hidden racism in the radical metaphor. Maizie was clearly moving toward culturally and politically relevant teaching through her role as a radical. However, she continued to see her role as overwhelming and too much to do. She was acutely uncomfortable with visiting parents as she did during that one summer and repeatedly told me that she didn't understand why the connections with the community were so important: "I am just overwhelmed and I went to visit the parents and it was good, but honestly I don't have much in common with them and I felt really uncomfortable. I mean with all that I do, do I have to be friends with all these parents too?"

This frustration is evidence that Maizie still did not fully see herself as an ally with the communities of her students. She was comfortable in the classroom, acting in ways that were good for her students, but she felt that community and family outreach were out of her ability range.

Making connections with families and communities are central aspects to culturally relevant teaching. Critical multicultural educators have found that when teachers understand the worldview of communities of color and engage side by side in their struggle for justice, they are effective teachers of students of color. Seeing families positively is not enough; culturally and politically relevant teachers are engaged with the community in real and meaningful ways (Beauboeuf-Lafontant, 1999; Gay, 2000; Klug \& Whitfield, 2003; Ladson-Billings, 1994).

Maizie's role as teacher may be closest to what critical multicultural scholars describe as successful teachers of students of color, but her role is still limited. The problem is that in the context of Woodson School, Maizie sees her approximation of culturally relevant teaching as radical. This metaphor suggests that what the scholars describe as successful teaching 
for students of color may be even less common than we think. Radical implies a dramatic departure from the norm, and yet Maizie continued to engage in practices and beliefs that subtly sustain racism in schools. How, then, can we scholars effectively communicate and affect the beliefs and practices of White teachers of students of color so that teachers with the limitations of Maizie are not seen as radical, but as the norm?

\section{CONGLUSION}

Pam, Sylvia, Carmen, and Maizie each saw themselves as good teachers, but they each also fell short of what scholars identify as culturally relevant teaching - good teaching for students of color. The central metaphors that these teachers used to describe their roles as teachers of students of color offered some insight into exactly how they operated as teachers in a school that served mainly Black students. It is possible, however, to imagine that another teacher could share a different interpretation of the same metaphor and be more like the teachers described as culturally relevant. For example, a teacher could certainly define herself as an intercultural communicator and incorporate sophisticated understandings of White racism into her beliefs and practices. The role of the central metaphor in this study was to demonstrate how the words that teachers use to describe themselves may appear to be positive for students of color, yet may function to permit beliefs and practices that sustain racism in schools. Their roles as teachers have both ideological and material effects for the students in their classrooms.

Pam was a benefactor to students and their families. The role of helpful hero implies some sense of superiority. Like the missionary ideology of other White teachers (McIntyre, 1997), this identity relied on the assumption of White superiority to maintain itself. For Pam, Whiteness was a condition upon which her role rested. One notable material effect of this role included the infrequency with which students were declassified of the stigmatizing special education label and the frequency by which they were labeled and thereby "helped."

Sylvia's role as a White person was an assimilated role through which she denied her Latina heritage. If she were to become aware of Whiteness as a system of discrimination, her identity would also be called into question in a different way than Pam's would. Sylvia chose Whiteness as an identity in opposition to something that she saw as negative: Latina identity. Her choice of Whiteness rested on the assumption of White superiority, and moreover, on the assumption of the inferiority of people of color. The historical pattern of "passing" is based on the implicit understanding that being White affords certain benefits and privileges. One of the material effects of this choice of identity was the negative assumptions about her students and the poor relationships that she had with her students and 
their families. Sylvia consistently saw her students in negative terms and was certain that if they could assimilate to Whiteness, they would be far better students.

Carmen's identity as an intercultural communicator relied on Whiteness for the privilege of appropriating another culture. She relied on her Whiteness to gain access to a variety of cultural settings and was able to imitate the cultural forms of expression among these groups. She was able to effectively communicate and create good relationships with the families of her students. This role of intercultural communicator functioned to mask Whiteness as a dominant and oppressive culture. However, by seeing Whiteness as a distinct culture, Carmen was able to reject the deficit explanations for racial inequality; instead, Carmen uses a cultural difference explanation. Carmen's central metaphor and role as teacher had the contradictory effects of interrupting and maintaining certain White racist structures. In spite of her positive relationships with her students' families, her appropriation and imitation of cultural norms possibly preserved a history of subjugation. Her restricted focus on culture as the salient feature of race relations may have created an uncritical interpretation of school structures that disproportionately place students of color at a disadvantage.

Maizie's role as a radical allowed her to see Whiteness as a tool of domination and as a means to maintain the status quo. Because she saw herself as a radical learner committed to democracy, she defined herself in political terms. She had not yet fully allied herself with a political struggle for the abolition of Whiteness, but she had altered her actions and teaching toward those political ends. The material effect of this identity is a critical engagement with students about the representations of racial groups in the curriculum. It facilitated critical thinking in her classroom. It did not, however, have the transformative effect of building a political alliance with the local community.

The Corbel context and the dominant educational discourses offer some insight into how these teachers understood their roles as teachers of students of color. The case of Pam, the helper, could have been influenced by the dominant discourse of charity and compassionate conservatism in the United States. This kind of helping on the part of White people serves to perpetuate patronizing forms of Whiteness and racism grounded in historic, hierarchical race relationships. In Pam's framework, some people are in need of help because they are unable to help themselves. Pam did not see that her interpretation was related to her Whiteness or that her helping presumed a deficit in those she was helping. At the same time, Pam worked within the Corbel context in which teachers are identified along with the students as the reasons for the school's failure to adequately educate all their students. Teachers are castigated for not doing their jobs, for being the cause of the problem. In Corbel, it was common for Woodson teachers to be told that they shouldn't work at Woodson for too long because 
they would be unlikely to find a job elsewhere. The accepted discourse was that Woodson's teachers were the worst in the district. Given this environment, choosing the role of helper is a way to preserve pride in oneself as a teacher.

The powerful influence of racism in the Corbel context also served to reify Sylvia's desire to assimilate to Whiteness. In Corbel, Woodson was seen the worst school because of the teachers and because of the students, who were primarily Black. By denying her own identity as a person of color and adopting Whiteness, Sylvia demonstrated the racial hierarchy within this context that seemed to lump students and teachers together regardless of race. Sylvia's case highlights how the power of Whiteness and White racism can operate among teachers of color so that they may deny significant aspects of who they are, and therefore see themselves as better than the students of color they serve. To acknowledge Whiteness as a system of domination and oppression would pose a serious challenge, particularly within a school and system that so clearly positions the identities of people of color as pathological.

Carmen's role as intercultural communicator also seems linked to the Corbel context. In Corbel, racism was never explicitly mentioned, even in the context of an investigation by the Office of Civil Rights. In the Corbel context, White was not even recognized as a race. So, to be blind to the power struggle of racism and see racial problems merely as an issue of cultural miscommunication seems natural. For Carmen, Whiteness was not even something that she had considered before beginning an examination of race and racism.

Finally, Maizie's role identification as a radical also makes sense within a local and national context that rarely emphasizes race and racism as a salient factor in education. Certainly, her willingness to examine the role and significance of Whiteness and racism with her students is unique in schools and communities that do not typically allow such terms into the discussion.

That Maizie can be seen as a radical points to the failure of critical multicultural educational researchers to adequately affect the field in which we work. We have had a definition of culturally relevant teaching for over a decade. There is little debate that the notion of culturally relevant teaching is valid and describes teachers who are successful with their students of color. Yet, we find teachers in schools who have radically different views of what it means to be a good teacher of students of color. In my work with these teachers, I found that how they saw themselves as teachers was integrally related to how they understood race and racism. Although each of them made some progress toward culturally relevant teaching, it was to very different degrees and fraught with self-doubt. I spent 3 years in conversation with these teachers and 23 others at the school and found that their resistance to seeing racism and examining Whiteness was strong and reified by the context in which they worked. 
Critical multicultural teacher educators and researchers have not yet found an effective way to talk across the chasm that divides the academy and the working lives of teachers. We have a responsibility as leaders in the field of education to change the cultures of schools and school districts so that culturally relevant teaching is not seen as radical and impossible but simply the norm. I am still searching for this way, but I have found through this analysis that I will work more closely to understand how and why teachers see their roles in particular ways. By working with a whole staff, the impact of this work was diluted because I could only see teachers periodically. As critical multicultural teacher educators and researchers, we must continue to find ways to work with small groups of teachers in intense longterm partnerships to begin to counter the racism that is embedded in the schools in which they teach and even within their own definitions of successful teaching.

\section{NOTE}

1. All proper names in this research have been changed to preserves the identities of the participants.

\section{REFERENCES}

Allen, T. W. (1994). The invention of the White race: Racial oppression and social control. London: Verso.

Beauboeuf-Lafontant, T. (1999). A movement against and beyond boundaries: Politically relevant teaching among African American teachers. Teachers College Record, 100, 702-723.

Bogdan, R., \& Biklen, S. K. (1992). Qualitative research for education: An introduction to theory and methods. Boston: Allyn \& Bacon.

Denzin, N., \& Lincoln, Y. (Eds.). (1994). Handbook of qualitative research. London: Sage.

Denzin, N. K. (1994). Symbolic interactionism and cultural studies: The politics of interpretation. Cambridge, MA: Blackwell.

Feagin, J. R., \& Vera, H. (1995). White racism. New York: Routledge.

Fine, M. (1991). Framing dropouts: Notes on the politics of an urban public high school. Albany: State University of New York Press.

Foster, M. (1997). Black teachers on teaching. New York: New Press.

Frankenberg, R. (1997). Introduction: Local Whitenesses, localizing Whiteness. In R. Frankenberg (Ed.), Displacing Whiteness: Essays in social and cultural criticism (pp. 1-33). Durham, NC: Duke University Press.

Gay, G. (2000). Culturally responsive teaching: Theory, research and practice. New York: Teachers College Press.

Giroux, H. A. (1997). Rewriting the discourse of racial identity: Towards a pedagogy and politics of Whiteness. Harvard Educational Review, 67, 285-320.

Gutierrez, R. (1999). Advancing urban Latina/o youth in mathematics: Lessons from a successful mathematics department. The Urban Review, 31(3), 263-281. 
Hyland, N. E. (2000). Threatening discourse: Cultural and contextual challenges in constructing antiracist narrative and action in one elementary school. Unpublished doctoral dissertation, University of Illinois at Urbana-Champaign, Urbana, IL.

Ignatiev, N. (1995). How the Irish became White. New York: Routledge.

Irvine, J. J., \& York, D. E. (1993). Teacher perspectives: Why do African-American, Hispanic, and Vietnamese students fail? In S. W. Rothstein (Ed.), Handbook of schooling in urban America (pp. 160-173). Westport, CT: Greenwood Press.

Kailin, J. (2002). Antiracist education: From theory to practice. Lanham, MD: Rowman \& Littlefield.

Klug, B. J., \&Whitfield, P. T. (2003). Widening the circle: Culturally relevant pedagogy for American Indian children. New York: Routledge Falmer.

Ladson-Billings, G. (1994). The dreamkeepers: Successful teachers of African American children. San Francisco: Jossey-Bass.

Ladson-Billings, G. (1998). Just what is critical race theory and what is it doing in a nice field like education? International Journal of Qualitative Studies in Education, $11,7-24$.

Lakoff, G., \& Johnson, M. (1980). Metaphors we live by. Chicago: University of Chicago Press.

Landsman, J. (2001). A White teacher talks about race. Lanham, MD: Scarecrow Press.

McCarthy, C. (1993). Multicultural approaches to racial inequality in the United States. In L. A. Catenell \& W. F. Pinar (Eds.), Understanding curriculum as racial text: Representations of identity and difference in education (pp. 225-246). Albany: State University of New York Press.

McIntyre, A. (1997). Making meaning of Whiteness: Exploring racial identity with White teachers. Albany: State University of New York Press.

Michie, G. (1999). Holler if you hear me: The education of a teacher and his students. New York: Teachers College Press.

Morrison, T. (1998). Home. In W. Lubiano (Ed.), The house that race built (pp. 3-12). New York: Vintage Books.

Paley, V. G. (2000). White teacher. Cambridge, MA: Harvard University Press.

Roediger, D. R. (1990). The wages of Whiteness: Race and the making of the American working class. London: Verso.

Roediger, D. R. (1994). Towards the abolition of Whiteness: Essays on race, politics, and working class history. London: Verso.

Ryan, W. (1976). Blaming the victim. New York: Vintage.

Sleeter, C. E. (1996). White silence, White solidarity. In N. Ignatiev \& J. Garvey (Eds.), Race traitor (pp. 257-265). New York: Routledge.

Twine, F. W. (1997). Brown-skinned White girls: Class, culture, and the construction of White identity in suburban communities. In R. Frankenberg (Ed.), Displacing Whiteness: Essays in social and cultural criticism (pp. 214-243). Durham, NC: Duke University Press.

Villegas, A. M., \& Lucas, T. (2002). Educating culturally responsive teachers: A coherent approach. Albany: State University of New York Press.

Zinn, H. (1995). A people's history of the United States: 1492-present. New York: HarperCollins. (Original work published 1980) 